\title{
The politics of silicosis in interwar Spain: Republican and Francoist approaches to occupational health
}

\author{
Alfredo Menéndez-Navarro \\ Department of History of Science, University of Granada. amenende@ugr.es
}

Dynamis

[0211-9536] 2008; 28: 77-102
Fecha de recepción: 1 de febrero de 2008

Fecha de aceptación: 13 de abril de 2008

SUMMARY: 1.-Introduction. 2.-Social reform and the emergence of silicosis in interwar Spain. 3.-Tackling silicosis during the Republic: the Law of Occupational Diseases and the Foundation for the Fight against Silicosis. 4.-Autarky, social insurance and political repression: approaching silicosis during the First Francoism. 5.-The Silicosis Scheme in early Francoist Spain (1941-1946). 6.-Conclusions.

ABSTRACT: This article explores the emergence and recognition of silicosis as an occupational disease in interwar Spain. Following International Labour Office guidelines, growing international concerns and local medical evidence, Republican administrators provided the first health care facilities to silicosis sufferers, who eventually became entitled to compensation under the Law of Occupational Diseases (1936), poorly implemented due to the outbreak of the Civil War (1936-39). Silicosis became a priority issue on the political agenda of the new dictatorial regime because it affected lead and coalmining, key sectors for autarchic policies. The Silicosis Scheme (1941) provided compensation for sufferers, although benefits were minimised by its narrow coverage and the application of tight criteria.

PALABRAS CLAVE: silicosis, enfermedades profesionales, legislación compensadora, II República, Primer Franquismo, España.

KEYWORDS: silicosis, occupational diseases, workmen's compensation, Second Republic, First Francoism, Spain. 


\section{Introduction $(*)$}

Over the past two decades, the history of industrial hazards has received growing historiographical attention. Much of that production has been concerned with the processes of recognition, regulation and compensation of work-related diseases. Silicosis, a chronic lung disease caused by the inhalation of silica dust, has represented an exemplary case study in this field. After David Rosner and Gerald Markowitz's pioneering works on silicosis regulation in the United States ${ }^{1}$, several national cases have come under historical scrutiny ${ }^{2}$. All of them showed how the emergence and recognition of silicosis as a major health problem was shaped in every case by a singular combination of social, political and economic forces as well as technical and scientific ones.

$\left({ }^{*}\right)$ This research was supported by the Spanish Ministry of Education Project HUM2006-02885 «The Fight against Silicosis in Spain (1930-1975)».

1. Rosner, David; Markowitz, Gerald, eds. Dying for work: workers' safety and health in twentiethcentury America, Bloomington: Indiana University Press; 1987; Markowitz, Gerald; Rosner, David. The Illusion of Medical Certainty: Silicosis and the Politics of Industrial Disability, 1930-1960. In: Rosemberg, Charles E.; Golden, Janet, eds. Framing Disease: Studies in Cultural History. New Brunswick: Rutgers University Press; 1991, p. 185-205; Rosner, David; Markowitz, Gerald. Deadly Dust: Silicosis and the Politics of Occupational Disease in Twentieth-Century America. Princeton: Princeton University Press; 1991.

2. Katz, Elaine N. The White Death: Silicosis on the Witwatersrand Gold Mines, 1886-1910. Johannesburg: Witwatersrand University Press; 1994; Derickson, Alan. Black Lung: Anatomy of a Public Health Disease. Ithaca: Cornell University Press; 1998; Thönquist, Annette. The Silicosis Problem in the Swedish Iron and Steel Industry during the 20th Century. In: Work Life, Work Environment and Work Safety in Transition. Historical and Sociological Perspectives on the Development in Sweden during the 20th Century. Stockholm: National Institute for Working Life; 2001, p. 71-101; Carnevale, Francesco; Baldasseroni, Alberto. A long-lasting pandemic: diseases caused by dust containing silica: Italy within the international context. Medicina del Lavoro. 2005; 96 (2): 169-176; Vergara, Angela. The Recognition of Silicosis: Labor Unions and Physicians in the Chilean Copper Industry, 1930s-1960s. Bulletin for the History of Medicine. 2005; 79: 723-748; Bufton, Mark W.; Melling, Joseph. Coming Up for Air: Experts, Employers, and Workers in Campaigns to Compensate Silicosis Sufferers in Britain, 1918-1939. Social History of Medicine. 2005; 18: 63-86; Bufton, Mark W.; Melling, Joseph. "A Mere Matter of Rock": Organised Labour, Scientific Evidence and British Government Schemes for Compensation of Silicosis and Pneumoconiosis among Coalminers, 1926-1940. Medical History. 2005; 49 (2): 155-178; Morrison, Sue. The Factory Inspectorate and the Silica Dust Problem in UK Foundries, 1930-1970. Scottish Labour History. 2005; 40 :31-49; Mclvor, Arthur; Johnston, Ronnie. Miners' Lung: A history of dust disease in British coal mining. Aldershot: Ashgate Press; 2007; Devinck, Jean-Claude; Rosental, Paul-André. Histoire d'une maladie professionnelle «exemplaire»: la silicose en France au XXe siècle. La Lettre de la Mire. 2007; 14: 2-5. 
The aim of this paper is to explore the Spanish case, which has received scant attention from historians ${ }^{3}$. Thus, attention will be paid to the emergence of silicosis as a health issue in interwar Spain and to the changing approaches to the issue during this period. Spain featured two specific characteristics in the European interwar context that to a great extent shaped labour and social legislation. First, the country experienced a radical political change in 1931 with the proclamation of the Second Republic. The International Labour Office (hereafter ILO) programme of protection for the working classes played a major role in the Republican labour legislation ${ }^{4}$. Second, after a dramatic Civil War (1936-39), the country lived under a strict dictatorship of fascist inspiration that established a framework of repression that contributed to the annihilation of the workers' movement. Thus, this first approach will focus on the institutional and legislative settings and particularly the changing strategies employed to fight silicosis during the Republican period and the so-called «First Francoism», i.e., from the Civil War to the early 1950s, when the Franco dictatorship aligned itself with Western strategies, bringing an end to the international isolation of the regime. In so doing, this paper attempts to offer an insight into elements of rupture and continuity between the democratic and the

3. Only local historians, especially labour historians interested in the Franco Regime, have addressed this industrial disease, which is central to understanding both social and labour relations in some key sectors of the Spanish economy and the workers' movement in interwar and Franco Spain. See García Piñeiro, Ramón. Los mineros asturianos bajo el franquismo (1937-1962). Madrid: Fundación 10 de Mayo; 1990; Benito del Pozo, Carmen. La clase obrera asturiana durante el franquismo. Empleo, condiciones de trabajo y conflicto (1940-1975). Madrid: Siglo XXI de España; 1993; Cohen, Aron; Ferrer, Amparo. Accidentes y enfermedades profesionales de los mineros: realidad y derecho. In: Huertas, Rafael; Campos, Ricardo, eds. Medicina social y clase obrera en España (siglos XIX-XX). Madrid: FIM; 1992, p. 215-244; Díaz Martínez, Irene; García Fernández, Carlos. Enfermedad profesional, redes de solidaridad y acción colectiva en la minería asturiana durante el franquismo. Sociología del Trabajo. 2007; no 59: 103-130.

4. ILO encouraged the establishing of standard national industrial-welfare legislation in the interwar years, mainly concerned with the extension of social insurance benefits, including compensation for accidents and occupational diseases. In addition to this programme, which was aimed at giving social stability to the post-war order, ILO studies and reports on occupational health in the early 1920s became instrumental in supporting workers' national demands for better workplace health conditions and in fostering medical profession awareness of industrial hazards, including those posed by silica dust inhalation. Weindling, Paul. Social medicine at the League of Nations Health Organisation and the International Labour Office compared. In: International health organisations and movements, 1918-1939. Cambridge: Cambridge University Press; 1995, p. 134-153. 
fascist health administrators responsible for dealing with occupational diseases in interwar Spain.

First, I will provide a brief outline of the social reform movement in 1920s Spain as well as a general overview of the emergence of the silicosis problem in different productive sectors. Second, I will explore the legal and healthcare approach of the Republican Governments to this issue. Third, I will summarise the main features of the Franco regime's social policies and explore the core of the struggle against silicosis in Franco's Spain, which was the Silicosis Scheme founded in 1941. I will focus on the characteristics of this compensation scheme, its performance and development in the 1940s and its main shortcomings.

\section{Social reform and the emergence of silicosis in interwar Spain}

Industrial hygiene and medicine became fully incorporated into the Spanish political agenda in the first decade of the 20th century, when social reform made its presence strongly felt in public affairs ${ }^{5}$. The path and strategies of reformist political sectors radically changed in the 1920s as a consequence of the crises caused by the international revolutionary upsurge of the years 1917-1921 and the effects of the Great War in Spain. The crisis prompted the adoption of policies aimed at promoting social peace, notably by social insurance, perceived as urgent due to the scant development of voluntary insurance among Spanish workers. Employers continued to be reluctant to support compulsory insurance schemes, whereas unions' demands intensified following international guidelines proposed by the $\mathrm{ILO}^{6}$.

5. Menéndez-Navarro, Alfredo; Rodríguez-Ocaña, Esteban. From «Accident Medicine» to «Factory Medicine»: Spanish Occupational Medicine in the Twentieth Century. In: Grieco, A.; Fano, D.; Carter, T.; lavicoli, S., eds. Origins of Occupational Health Associations in the World. Amsterdam: Elsevier Science B.V.; 2003, p. 207-216. Spanish social reformist's concerns were extended to several disorders identified as «social diseases» and defined both by their social aetiology and their demographic and economic impact, such as tuberculosis and infant mortality. Rodríguez-Ocaña, Esteban. Medicine as a Social Political Science: The Case of Spain c. 1920. Hygiea Internationalis. 2007; 7 (1): 37-52.

6. Porras Gallo, Maria Isabel. Medicine, social security, and occupational disabilities in Spain in the first half of the twentieth century. Historia ciencia saude-Manguinhos. 2006; 13 (2): 393-410. Cuesta Bustillo, Josefina. Los seguros sociales en la España del siglo XX. Hacia los seguros sociales obligatorios. La crisis de la Restauración. Madrid: Ministerio de Trabajo y Seguridad Social; 1988. 
Spanish socialist trade unions' demands prompted intense parliamentary activity on occupational health matters in the early 1920s. After a failed attempt in 1919, a new bill for the reform of accident legislation was put forward and successfully passed in 1922. The 1920 General Congress of the Socialist Union specifically demanded coverage of industrial diseases ${ }^{7}$. Parallel to this debate, convenors to the Spanish Congress of Work Accidents held in Saragossa in 1922 unanimously supported the need for a new law of occupational diseases that allowed its integration into the existing workmen's compensation system ${ }^{8}$. However, the employers' opposition proved effective, as the law did not extend coverage to occupational diseases ${ }^{9}$. In 1921, workers' delegates at the Institute for Social Reform, an advisory body set up to provide the scientific basis for reforming social legislation, promoted the drafting of a bill on compensation for industrial diseases. The bill included a wide range of pathological conditions grouped under three etiological categories (physical, mechanical and biological). However, the proposal did not reach Parliament, because it was dissolved and the Institute was suppressed in the aftermath of the coup d'état by General Primo de Rivera in September $1923^{10}$.

In this context, cases of silicosis began to be reported in the lead mining industry in the mid 1920s. The main lead mining operators, most of them non-Spanish large-scale companies, were concentrated in Southern Spain, especially in the province of Jaén. Together with the state-owned mine of Arrayanes in Linares, the leader of production was the British New-Centenillo Silver Lead Mines Company, founded in $1898^{11}$. It was probably the large size of companies operating in lead mining that facilitated the widespread use of mechanical drilling in the late $1910 \mathrm{~s}^{12}$ (Figure 1). Dr. Sánchez Martín (1872-1955), a factory doctor appointed in 1907 to the medical service

\footnotetext{
7. Cuesta Bustillo, n. 6, p. 703-704.

8. Fernández Aldama, M. Intoxicación mercurial profesional de los mineros de azogue. Zaragoza; Talleres Editoriales de Heraldo de Aragón: 1922.

9. Porras Gallo, n. 6, p. 398-400.

10. Consejo de Trabajo. Antecedentes relativos a la reparación de las enfermedades profesionales. Madrid: Imp. Sob. de la Suc. de M. Minuesa de los Ríos; 1934.

11. Martínez Ortiz, Juan José; Tarifa Fernández, Adela. Medicina social, demografía y enfermedad en la minería giennense contemporánea. El Centenillo: 1925-1964. Jaén: Diputación Provincial de Jaén; 1999.

12. Molina Vega, Agustín. El método de trabajo y el desarrollo tecnológico en el distrito minero de Linares-La Carolina. In: Artillo González, Julio et al. La minería en Linares (1860-1923). Jaén: Diputación Provincial, Ayuntamiento de Linares; 1987, p. 115-132 (p. 126).
} 


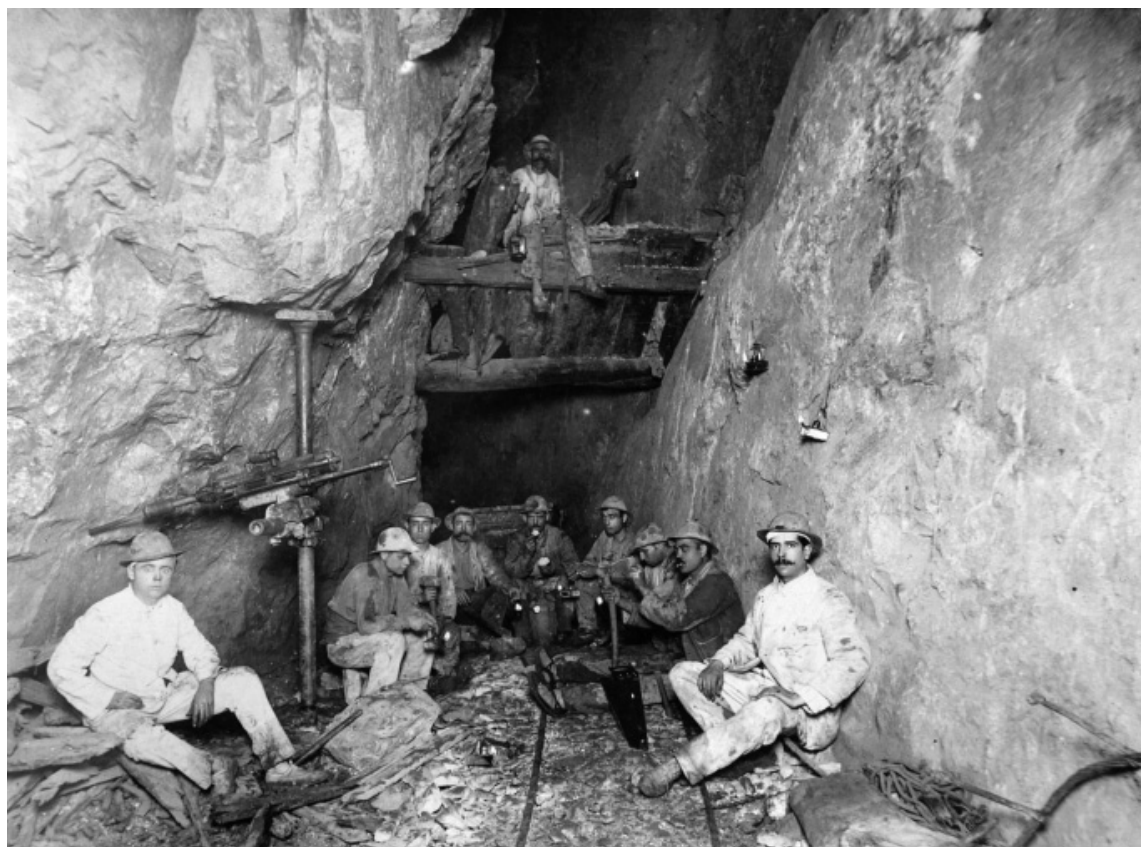

Figure 1. Linares' lead miners during a break (1914). Source: Photographic Collection, Series 01 Mines file 29. Historical Archive of the City of Linares (Jaén).

of the British company reported in 1921 on the inevitable onset of a new public health problem in the mining district, linked to the introduction of mechanical drilling and the lack of effective dust suppression measures. The company provided drillers with a local-made mask consisting of a wire frame and cotton filter that needed to be replaced daily ${ }^{13}$. In any case, the priority of the medical service was ancylostomiasis because this mining area, which had the highest infection rates in Spain, became the scenario for the campaigns against hookworm disease developed in collaboration with the Rockefeller Foundation. These campaigns led to the creation in 1926 of a

13. Sánchez Martín, Guillermo. De higiene minera. Revista Minero Metalúrgica y de Ingeniería. 1921; 57 (2791): 377-380. 
Mining Health Inspectorate in the area, which probably contributed to the early recognition of the silicosis problem ${ }^{14}$.

Lack of safety and unhealthy working conditions were among the main complaints made by lead miners in the late 1910s. Eight miners' strikes were reported in the Linares-La Carolina mining district between 1920 and $1923^{15}$. At the same time, lead prices collapsed in the international market, bringing crisis to the sector. In 1928 a National Lead Producers Association, including the state-owned mine of Arrayanes and the main private mining companies and foundries operating in Linares-La Carolina (province of Jaén) and Cartagena-Mazarrón (province of Murcia) districts, was promoted by the Government to cope with the economic crisis in the sector ${ }^{16}$. Organised as a trading network to protect local lead production, the Association became reluctant to get involved in non-productive measures.

In the early 1930s, concerns also grew in other sectors, especially coal mining and iron ore mining, activities mainly concentrated in the Asturian coal valleys and Basque Country, respectively. Earlier news on anthracosis in coal mining was included in Asturian medical geographies published during the $1920 \mathrm{~s}^{17}$. In the 1930s, reports on silicosis were issued by factory physicians or chest specialists with direct and frequent contact with exposed workers ${ }^{18}$.

In iron ore mining, medical reports were mainly issued by chest specialists. In 1933, an unpublished doctoral dissertation reported on some 25 silicosis sufferers, all of them iron mining drillers who were studied at the Basurto General Hospital in the Basque Country. The author reported on a recent strike and miners' protest, including demands for

14. Rodríguez-Ocaña, Esteban; Menéndez-Navarro, Alfredo. Higiene contra la anemia de los mineros. La lucha contra la anquilostomiasis en España (1897-1936). Asclepio. 2006; 58 (1): 219-248.

15. Garrido González, Luis. La minería y los problemas laborales. Nacimientos del movimiento obrero. In: Artillo González, Julio et al. La minería en Linares (1860-1923). Jaén: Diputación Provincial, Ayuntamiento de Linares; 1987, p. 161-187 (p. 184).

16. Gaceta de Madrid. 11 March 1928: 1600-1604; Gaceta de Madrid. 5 April 1928: 96-100.

17. García Fernández, Carlos. El archivo de HUNOSA y la construcción de la seguridad en la minería del carbón asturiana. Oviedo: HUNOSA; 2005, p. 58-60.

18. Álvarez-Buylla Godino, Plácido; Pumarino Alonso, Joaquín. Sobre pneumoconiosis en los mineros de carbón. Progresos de la clínica. 1933; 41: 706-716; and, Silicosis en los mineros del carbón: consideraciones radiológicas y clínico-profilácticas. Oviedo: Esc. Tipográfica de la Residencia Provincial de Niños; 1934; Andrés Bueno, Vicente de. La silicosis de los mineros de carbón en España. Revista Clínica Castellana. 1935; 2: 1-12; Morayta Serrano, Francisco. Estudio sanitario de las minas de carbón en España. Madrid: Gráfica Universal; 1936. 
better wages and masks to prevent dust inhalation ${ }^{19}$. The clinics of the Anti-tuberculosis National Foundation also became active in reporting on silicosis cases ${ }^{20}$. Other reports came from local doctors settled in the iron mining area ${ }^{21}$.

Eventually, statistical analyses and reviews of international medical literature and legislation were also published ${ }^{22}$. Generally speaking, the above-mentioned Spanish medical literature clearly identified silicosis as an autonomous disease that was differentiated from tuberculosis and linked to inhalation of dust containing silica at the workplace. On the other hand, silicotic lungs were considered prone to tuberculosis infection. Despite this association with working conditions and the focus on silica dust, however, the physical characteristics and lifestyles of individuals were still considered relevant factors in the onset and development of the disease. In line with J.S. Haldane's views, authors supported the harmlessness of inhaled coal dust.

Medical reports unanimously called for the government to integrate silicosis into the existing workmen's compensation system and pressed for legal recognition of silicosis as a compensable disease. The healthy problem was perceived as affordable ${ }^{23}$, while the most pessimistic estimations talked of 100,000 workers exposed to this hazard in Spain ${ }^{24}$.

19. Burzaco, José María. Silicosis y sílicotuberculosis. Estudio anatomoclínico y radiológico. Madrid: Facultad de Medicina de la Universidad Central; 1933.

20. Aura Riera, V; González Rubio, L. Estudio clínico de dos casos de Neumoconiosis, uno de ellos asociado a Tuberculosis. Revista Española de Tuberculosis. 1932; 3 (6): 597-609; Izquierdo Laguna, Silvano; García Sainz, Eusebio. Silicosis. Bilbao: Imprenta Editorial Moderna; 1945. p. 169.

21. Lartitegui Arenaza, Jesús. Pneumoconiosis silicóticas. Madrid, Facultad de Medicina de la Universidad Central; 1934. This doctoral dissertation provided original data on 15 silicosis sufferers from the iron mines of Somorrostro.

22. García Triviño, Felipe. Los problemas clínicos y médico-legales en la silicosis pulmonar. La Medicina Ibera. 1933; 27 (2): 73-76; Lartitegui Arenaza, Jesús. Pneumoconiosis silicóticas. Bilbao: Imprenta Docmao; 1933; Rapado Pozas, Aurelio. Estudio de las pneumoconiosis. Madrid: Facultad de Medicina de la Universidad Central; 1933; Dantín Gallego, Juan. Silicosis: Conferencia del ciclo organizado por la Asociación de Graduados y Alumnos de la Escuela Social de Madrid. Madrid: Imp. Suc. de Minuesa; 1936.

23. Andrés Bueno, n. 18, p. 5.

24. Lartitegui Arenaza, n. 22, p. 67; Dantín Gallego, n. 22. 


\section{Tackling silicosis during the Republic: the Law of Occupational Diseases and the Foundation for the Fight against Silicosis}

The appointment of the Spanish socialist leader Largo Caballero (1869-1946) as the first Minister of Labour of the Spanish Republic in 1931 inaugurated an intense period of moderate social reformism. The enactment of labour legislation in the so-called Progressive Two-Year Period (1931-33) contributed both to the empowerment of the Socialist Trade Union and the betterment of workers' living and working conditions ${ }^{25}$.

The commitment of the Republican Government to the improvement of workers' health conditions was reflected in the extension of workmen compensation to rural workers in 1931 and the enactment in 1932 of a new Law of Work Accidents under which accident insurance became compulsory for most economic activities ${ }^{26}$. Furthermore, the Government encouraged the ratification of a significant number of ILO conventions postponed by previous Governments, and their corresponding incorporation into Spanish legislation.

In 1925, the ILO adopted a convention for workmen's compensation for occupational diseases that only included lead and mercury poisoning and anthrax infection. Subsequently, occupational diseases and silicosis compensation became central issues at different international meetings. The Fourth Session of the Permanent International Committee on Occupational Diseases (Lyon, April 1929) approved a resolution from the French Confédération Générale du Travail to add silicosis to the list covered by the French Law of Occupational Diseases (issued 1919) ${ }^{27}$. An International Silicosis Conference was held in Johannesburg in August 1930. It was the first ILO international meeting to have focused on a single occupational disease and was committed to make available internationally the experience on silicosis in South African gold mining. This meeting, with convenors invited from

25. Juliá Díaz, Santos. Objetivos políticos de la legislación laboral. In: Tuñón de Lara, M.; García Delgado, J.L., eds. La Segunda República Española: El primer bienio. III Coloquio de Segovia sobre Historia Contemporánea de España. Madrid: Siglo XXI; 1987, p. 27-47.

26. Martínez Pérez, José. La salud laboral en la II República: la actitud de los médicos ante la Ley de Accidentes de Trabajo en la Industria. In: Huertas, Rafael; Campos, Ricardo, eds. Medicina social y clase obrera en España (siglos XIX y XX). Madrid: Fundación de Investigaciones Marxistas; 1992, p. 349-369.

27. Buzzi, Stéphane; Devinck, Jean-Claude; Rosental, Paul-André. La santé au travail (1880-2006). Paris: La Découverte; 2006, p. 31-32. 
eight countries, contributed to triggering international concerns about this occupational health hazard and generating a growing scientific consensus on etiological, diagnosis and preventive aspects of silicosis ${ }^{28}$. Although Spain had no direct participation in either meeting, these debates were widely reported in the Spanish medical literature. Eventually, the 1925 Convention was revised in 1934 at the 18th session of the General Conference of the ILO, with the addition of various entities, including silicosis, to the list of occupational diseases covered ${ }^{29}$.

In a tour de force during the winter of 1931 and the spring of 1932, the Spanish Parliament ratified 14 out of the 15 proposals sent by the Labour Council $^{30}$, including the 1925 ILO Convention on compensation for occupational diseases ${ }^{31}$. A first attempt to ratify this convention had previously failed in 1929. The ratification prompted a debate for a law of industrial diseases, and in May 1932 the Labour Council launched a public inquiry on this issue ${ }^{32}$. Proposals were sent by seven employers' associations, including insurance, mining and metallurgical companies, eight trades unions, two official bodies and one medical expert, Dr. Vicente de Andrés Bueno. The list of diseases covered by the law became the most controversial item in the inquiry. Employers and insurance companies restricted the list to those approved by ILO in 1925, i.e., lead and mercury poisoning and anthrax infection. The set of industrial diseases proposed by labour unions for compensation widely exceeded this list, including: pathological effects of

28. Bureau International du Travail. La Silicose. Compte rendu de la Conférence internationale tenue à Johannesburg du 13 au 27 août 1930. Genève: BIT; 1930.

29. International Labour Organisation. International Labour Conventions and Recommendations, 1919-1981. Geneve: ILO; 1982.

30. This commitment was especially welcomed by ILO chief Albert Thomas, who expressed satisfaction at the capacity of the democratic republican government to match fascist regimes' social policy achievements. Cuesta Bustillo, Josefina. Una esperanza para los trabajadores. Las relaciones entre España y la Organización Internacional del Trabajo (1936-1939), Vol. I. Madrid: Consejo Económico y Social; 1994, p. 271-275, 285.

31. Gaceta de Madrid. 14 April 1932: 335. Prior to its ratification, Andrés Bueno published a thorough study on the convention, its advantages and shortcomings and the implications of its implementation for Spanish economy. Andrés Bueno, Vicente de. Estudio médico-social del convenio sobre reparación de las enfermedades profesionales aprobado en la 7a Reunión (mayo-junio de 1925) de la Conferencia Internacional del Trabajo. Examen crítico de su posible aplicación a la economía española. Madrid: Imprenta Helénica; 1932.

32. Gaceta de Madrid. 18 May 1932: 1293-1294. The failure to ratify the legislation in 1929 was due to its rejection by the Labour Council, which considered it appropriate but premature. Consejo de Trabajo, n. 10, p. 55. 
exposure to phosphorus, arsenic, benzene, $\mathrm{X}$-rays, cement, or compressed air; conditions derived from the handling of tar, mineral oil and paraffin; and infectious diseases, e.g., ancylostomiasis, typhus, etc. The Miners Union of Asturia, the majority union within coal mining, proposed the inclusion of diseases caused by dust, e.g., silicosis, anthracosis, calicosis and siderosis. Other unions' demands reflected the bitter experience of three decades of work accident compensation in Spain, with the abuses of insurance companies and the failures of employers, calling for compulsory insurance, a national insurance fund, the awarding of life annuities rather than a single payment, and the speeding up of compensation claims ${ }^{33}$.

Some organisational changes introduced in 1933 and 1934 exemplified how the Republican Administration was encouraging not only the extension of social insurance but a wider concept of occupational health. The Clinic for Industrial Medicine of the National Insurance Institute opened in April $1933^{34}$. The Clinic provided the specialised care imposed by 1932 accident legislation and became the reference centre for specialist training in occupational medicine. In fact, these courses were regarded as a preferential condition for gaining a position in the Medical Inspectorate of Work, founded in August $1934^{35}$. The establishment of a specialised medical branch within the Work Inspectorate was completed a month later with the creation of an Industrial Hygiene Service under the State Office of Public Health. The new service absorbed the tasks of the former Mining Health Inspectorate (1926-1930) and was in charge of coordinating all official bodies dealing with medical prevention and industrial hygiene. In particular, the Service was committed to the implementation of the relevant international conventions ratified by the Spanish Government ${ }^{36}$.

The debate on the law of occupational diseases gathered momentum in 1934 and paralleled the above-mentioned organisational changes and the revision of the 1925 ILO Convention. The Labour Council drafted a bill in

\footnotetext{
33. Consejo de Trabajo, n. 10, p. 56-66.

34. The National Insurance Institute (founded in 1908) was the official body in charge of promoting and administering social insurance in Spain. See Montero García, Feliciano, ed. Los seguros sociales en la España del siglo XX. Orígenes y antecedentes de la previsión social. Madrid: Ministerio de Trabajo, Universidad de Salamanca; 1988.

35. Menéndez-Navarro; Rodríguez-Ocaña, n. 5, p. 210.

36. Gaceta de Madrid. 6 October 1934: 189-190. For a general description of these official bodies see Bartolomé Pineda, Ángel, ed. Historia de la Medicina del Trabajo en España (1800-2000). Madrid: Fundación MAPFRE Medicina; 2004.
} 
January 1934 and sent it for assessment to the National Insurance Institute. The technical report, prepared a few weeks later, reflected the lack of consensus within the Institute ${ }^{37}$. The main resistance came from the Institute's legal advisor, who argued that the new law would imply a restriction of workers' rights, since only a short and restricted list of industrial diseases linked to certain occupations would be entitled for compensation. In his opinion, the concept of accident in Spanish legislation was all-inclusive and could be extended to cover all diseases associated with employment. This interpretation was supposedly endorsed by High Court case law. In fact, the Spanish High Court had passed 54 sentences from 1903 to 1934 awarding compensation for workers claiming recognition of an occupational disease under the Accident legislation ${ }^{38}$. Paradoxically, however, these sentences reflect the usually restrictive interpretation of accident compensation legislation by the courts. Most of the sentences (72\%) had been passed after 1920 , in a period of special social unrest, and a quarter of the sentences were related to lead poisoning cases. Only two cases were described as chronic lung diseases. Hence, the conception of industrial disease appears to have been limited to acute and chronic poisoning rather than chronic lung impairments. In an inquiry carried out in Asturian coal valleys in 1933, no case was reported of a miner who had been awarded compensation for lung disease caused by dust inhalation ${ }^{39}$.

The Permanent Commission of the Labour Council - with a tripartite representation from Government officials, employers and workers- redrafted the bill in March 1934. The bill encompassed some of the unions' demands and echoed the most important features of the 1932 Law of Accidents. First, insurance became compulsory for the industries contemplated in the law. In the case of silicosis, this meant «all industries that exposed their workers to the risk of silicosis». Second, an insurance fund was set up to protect workers when employers were unable to pay. The coverage of the law became the grounds for bitter argument. Employers fiercely resisted an

37. Informe acerca del anteproyecto de bases sobre regulación específica de enfermedades profesionales. 25 January 1934. Historical Archive of the National Insurance Institute (Madrid) (hereafter HANII), file 46, sub file 1, document 9.

38. Anteproyecto de Bases para la aplicación del Convenio sobre Enfermedad Profesional. Informe del Asesor Jurídico. 16 January 1934. HANII, file 46, sub file 1, document 5; García Ormaechea, Rafael. La enfermedad profesional. Madrid: Publicaciones del Instituto Nacional de Previsión; 1933.

39. Andres Bueno, n. 18, p. 5. 
extension of the list to diseases other than those recognised in the 1925 ILO Convention. The Commission recommended the Government to include the diseases contemplated in the 1925 Convention and its 1934 revision and, eventually, those recognised as work accidents by the Spanish High Court since $1903^{40}$.

Employers' resistance and political crisis proved effective in delaying the passing of the law, which was postponed until $1936^{41}$. In the meantime, the Republican Government was inspired to adopt measures to tackle the silicosis issue by members of the Spanish delegation who attended the 18th session of the General Conference of the ILO in Geneva in June 1934, when the convention on occupational diseases was revised ${ }^{42}$. In August 1935, the Government partially modified the activity of the National Lead Producers Association, whose performance to alleviate the crisis in the sector was positively valued. Among these changes was the creation of a charity funded by employers and the State to provide health care for «lead miners who have caught chest disease for silicosis derived from the employment of mechanical drilling» ${ }^{43}$. A month later, the Foundation for the Fight against Silicosis (hereafter FFAS) was established, focusing its activities in the lead mining district of Jaén. The FFAS developed a healthcare-oriented policy, running a specialised clinic in the town of Linares. Benefits were limited to medical examination and health care, and were preferably assigned to lead mine drillers with silicosis whose health state could be improved ${ }^{44}$.

The clinic started to work in a provisional site (probably the Secondary Rural Health Centre of the town) in October 1935. Despite the rapid collaboration of the City Council in providing premises for building the clinic, a location change proposed by the FFAS in May 1936 postponed the final approval of the project until June 1936, just a month before the outbreak of the Civil War ${ }^{45}$. The clinic worked without interruption until early

\footnotetext{
40. Consejo de Trabajo, n. 10, p. v-xi. International Labour Organisation, n. 29, p. 662-664.

41. Cuesta Bustillo, n. 30, p. 295-296.

42. Leal y Leal, J. El problema de la silicosis en la zona minera de Linares y La Carolina. Medicina. 1943; 1: 375-383.

43. Gaceta de Madrid. 20 August 1935: 1512-1519.

44. Gaceta de Madrid. 24 September 1935: 2339-2340.

45. The original project was to locate the clinic close to the Secondary Rural Health Centre of Linares. The City Council ceded the premises and endorsed the architectural plan by May 1936. Nevertheless, the FFAS considered that this location at the top of the town and far from miners' quarters would not be convenient for silicosis sufferers, therefore a new site was proposed later that month. The building project included facilities for medical examina-
} 
1939, when the outcome of the war prompted its temporal closure. During the war, its output was hindered by personnel and funding problems. In addition, mobility problems prevented miners from the Centenillo mines, 40 kilometres from Linares, from visiting the clinic ${ }^{46}$. Thus, it was mainly local miners in poor health who sought help. From October 1935 to early 1939, 1027 miners were examined, 66\% (677) of whom were diagnosed with silicosis $(44 \%)$ or silico-tuberculosis $(22 \%)$ and only $13.5 \%$ of whom were classified as healthy. Dr. José Leal Leal, practitioner at the clinic and technical assistant to the FFAS since $1937^{47}$, estimated a rate of silicosis in pit-workers of $50 \%{ }^{48}$.

In addition to the clinic, a Silicotics Hospital was established in the city during the Civil War, managed by the Socialist General Union (UGT) and the anarchist union CNT. The hospital did not get official funding, therefore demands for free drugs from the municipal hospital and financial support from the Town Council were made in April 1937 and September 1938, respectively, arguing not only the needs of silicosis sufferers but also the leading role of Linares' miners in the fight against fascism ${ }^{49}$.

The setting up of the first medical facilities for sufferers was combined with the commissioning in late 1935 of the first general health survey on silicosis, albeit restricted to gold mining. Gold mining was limited in the mid-1930s to a small and successful British company operating in Southeast Spain. The company, Mines of Rodalquilar, started large-scale mining in 1930 with a workforce of around 170 pit-workers ${ }^{50}$. Silicosis rapidly emerged as a consequence of the introduction of mechanical drilling, which increased mineral extraction from 4,000 metric tons in 1931 to 20,000 in 1935. The Work Accidents Compensation Board (hereafter WACB), the body in charge of managing workers compensation insurance, ordered a medical examination of all pit-workers (120 at the time) and an analysis of the records kept in the Company's Medical Department from 1930. The research was carried out by Luis Ramallal, a young doctor trained at the

tions, X-rays, library and a small rest-room. Historical Archive of the City of Linares (Linares) (hereafter HACL), files 0541/053, 1109/046.

46. Leal y Leal, n. 42, p. 376. HACL, files 1931/045, 0549/067.

47. Gaceta de la República. 17 August 1937: 682.

48. Leal y Leal, n. 42, p. 376.

49. HACL, files 1922/034, 1989/042. The demand for free drugs supply was rejected but the Council met financial requirements of the hospital by allocating a monthly subsidy.

50. Hernández Ortiz, Francisco. Rodalquilar: Historia económica. Almería: GBG Editora; 2005, p. 36. 
Clinic for Industrial Medicine in Madrid ${ }^{51}$. A lung disease rate of over 35\% was reported, with cases of silicosis in men who had only been with the firm for less than two years. All of the 20 drillers who had been working for 5 years were found to have silicosis: 7 were diagnosed with third-degree silicosis, 2 with second-degree silicosis, 1 with first-degree silicosis and 10 had died that year. An autopsy had been undertaken in only five cases, but in all of them the rapid progression and death were interpreted as due to silico-tuberculosis. Among the remaining 100 miners examined, 22 were diagnosed with silicosis, $73 \%$ of them drillers ${ }^{52}$.

The author did not have a koniometer available, therefore no dust measurements were carried out. Nevertheless he linked the remarkably fast outset and development of silicosis in these mines with the high dust inhalation levels produced by the drilling techniques employed and the high rate of tuberculosis infection. As a consequence, he made recommendations both to reduce dust levels and prevent tuberculosis contagion and infection among miners. Technical suggestions included the introduction of water injection devices and the reduction in the number of mining shifts per day to allow the dust raised after blasting to be lowered to acceptable levels. Medical prevention was, once again, limited to previous and periodical medical examinations recommending compensation for workers who should be retired in early stages of the disease as prophylactic measure ${ }^{53}$.

Eventually, the bill was introduced in the Parliament on June 1936 and passed in July 1936, three days prior to the outbreak of the Civil War ${ }^{54}$. It is not easy to gauge the impact that the experiences of silicosis in lead and gold mining gathered by the Labour Ministry had on the new political situation created after February 1936 elections won by the so-called Popular Front and its intensive social and labour program ${ }^{55}$. But, it is clear that

51. Eventually the report became his doctoral dissertation defended after the war. Ramallal Rumbo, Luis. La silicosis en las minas de oro de Rodalquilar (Almería). Madrid: Universidad Central; 1940.

52. Ramallal Rumbo, n. 51, p. 35-38.

53. Ramallal Rumbo, n. 51, p. 4-6, 37-38, 58-59, 61-66.

54. Gaceta de Madrid. 4 June 1936: 2020-2022; 15 July 1936: 515-517. Prior to its passing, the bill gained the support of the Spanish Society of Occupational Medicine (founded in 1934), which discussed a paper on the issue at their second conference in January 1936. Andrés Bueno, Vicente de. Colaboración de la Sociedad Española de Medicina del Trabajo en la Legislación que se haga sobre Enfermedades Profesionales. Anales. 1935; 2 (21-24): 332-341.

55. Cuesta Bustillo, n. 30, p. 303-313. 
the parliamentary process leading to the passing of the Law of Industrial Diseases contributed to improvements in the bill.

The list of diseases entitled to compensation went beyond the widest criteria proposed by unions in the 1934 draft. In addition to the revised 1934 ILO Convention, a long series of conditions were entitled to compensation, including occupational dermatosis, ancylostomiasis, miners' nystagmus, Dupuytren's contracture or infectious diseases in healthcare professionals. Silicosis was placed in the group of pneumoconiosis that also included anthracosis and «any other lung diseases caused by dust» ${ }^{56}$. Furthermore, the law did not close the door to compensation under accident legislation of new diseases recognised by tribunals to be work-related.

The law introduced the principle of compulsory insurance and paralleled most of the achievements of the 1932 Accident Law. In terms of medical supervision and prevention, the law incorporated new rules. Whereas in the 1934 draft, medical assessment was contemplated as compulsory for workers in order to evaluate disability, the law established periodical medical supervision at least every 6 months to achieve an early diagnosis. Furthermore, employers were required to provide adequate prophylactic measures to workers and to pay for their hospitalisation if necessary. Periodical visits by the Factory Inspectorate and the Medical Inspectorate of Work to high-risk industries were also instituted. A Technical Central Commission on Occupational Diseases was set up to examine discrepancies and to propose the recognition and entitlement to compensation of new occupational diseases. The Commission was made up of the Chief of the Industrial Hygiene Service, medical experts and delegates from workers and employers organisations, with their corresponding medical advisors.

Implementation of the law was seriously hindered by the war. Although the Act became effective on 1 January 1937, a decree issued nine days later suspended its enactment, citing the impact of the war and technical difficulties in establishing employers' liability. Nevertheless, the Labour Ministry's concerns about silicosis prompted the adoption in April 1938 of provisions to guarantee silicosis compensation, regardless of whether the current or former employer was considered liable. A Technical Commission of the highest level was set up to sort out «any problems affecting silicosis» ${ }^{57}$.

56. It must be borne in mind that Spain did not ratify the 1934 Convention until March 1938. Gaceta de la República. 25 March 1938: 1471-1473.

57. Gaceta de la República. 1 May 1938: 631-632. 


\section{Autarky, social insurance and political repression: approaching silicosis during the First Francoism}

Recent historiography on Spanish civil post-war period has emphasised the role played by labour legislation within the effective framework of repression established by Franco regime ${ }^{58}$. In addition to the annihilation of the workers movement and restoration of social order, the legislation implemented by the Labour Ministry - led by the Falangist Girón de Velasco since 1941- deprived workers of any possible involvement in negotiating their working conditions, ensuring their subordination. The Labour Ministry combined this control policy with the implementation of social policies designed to widen the social basis of the new regime and modulate styles of life in accord with the new social values. Thus, «social justice» became one of the rhetorical icons to generate a social consensus. This political discourse was aimed at legitimising the regime among the less politically committed sectors of the population and also at attracting social groups clearly disaffected with the new regime ${ }^{59}$.

The new model of labour relations and the general principles of the regime's social policy were incorporated into the Labour Charter proclaimed by the Franco Government in March $1938{ }^{60}$. Inspired by the Italian Fascist Carta del Lavoro (1927), the Charter gave shape to the concept of the new corporative state. It legitimised the state control of labour relations on the grounds of the defence of workers and the search for national prosperity and social harmony. According to Falangist ideology and taking up corporatist ideas developed in the late 19th century, the country was conceived as a huge «union of producers». The Spanish population would be organised corporatively through a system of so-called vertical unions or syndicates corresponding to all basic areas of production, where employers and work-

58. Molinero, Carme; Ysàs, Pere. Workers and Dictatorship: industrial growth, social control and labour protest under the Franco regime, 1939-76. In: Smith, Angel, ed. Red Barcelona. Social protest and labour mobilization in the twentieth century. London: Routledge; 2002, p. 185-205; Molinero, Carme. El reclamo de la «justicia social» en la políticas de consenso del régimen franquista. Historia Social. 2006; 56: 93-110; Vilar Rodríguez, Margarita. El sistema de cobertura social en la inmediata posguerra civil (1939-1958): una pieza más de la estrategia represiva franquista. In: VI Encuentro de Investigadores sobre el Franquismo. Zaragoza, 15, 16 y 17 de noviembre de 2006. Zaragoza: Fundación Sindicalismo y Cultura, CC.OO.-Aragón; 2006, p. 619-634.

59. Molinero; Ysàs, n. 58, p. 186.

60. Boletín Oficial del Estado (hereafter BOE). 10 March 1938: 6178-6181. 
ers would be integrated under fascist party control. While industrialists could in most cases keep their own organisations, workers were deprived of the right to independent association and their class-based unions were banned ${ }^{61}$.

In 1940, the Spanish Syndicalist Organisation was established. In addition to its control over labour relations, the Organisation also participated in the implementation of welfare policies and the application of Labour Ministry social policies, lauded as the most advanced in the world. This welfare dimension became used as a formidable propaganda tool to represent the regime as a providing, magnanimous state ${ }^{62}$.

In this context, silicosis was maintained on the political agenda of the new dictatorial regime and was even a priority issue. Two main reasons can be proposed for this new emphasis. First, as has been explained, the extension of social and health insurance was part of a strategy of the Fascist regime to eradicate labour tensions and to widen social basis of the new regime. The Labour Charter, which established the general principles of social insurance policy in post-war Spain, explicitly included occupational diseases.

Second, following the devastation of the war and faced by the subsequent international isolation of Spain, the Franco Government based the rebuilding of the Spanish economy on a policy of protectionism that followed the Fascist party doctrine of national self-sufficiency and state control of «national industry». World War II and the immediate consequences of its outcome strengthened the new regime's commitment to autarky ${ }^{63}$. Mining production and coal and lead mining in particular were among the prime targets of this policy. Thus, the enactment of social policies that could contribute to increasing production in key sectors of the national economy and to bringing about the adhesion of the working class was a complement

61. Bengoechea, Soledad. The Barcelona bourgeoisie, the labour movement and the origins of Francoist corporatism. In: Smith, Angel, ed. Red Barcelona. Social protest and labour mobilization in the twentieth century. London: Routledge; 2002, p. 167-184.

62. Such a representation was conveyed by media, under a strict state control, and particularly by the Spanish Official Newsreel NO-DO, which held a thirty years monopoly over audio-visual information in Spain. Medina-Doménech, Rosa M.a; Menéndez-Navarro, Alfredo. Cinematic representations of medical technologies in the Spanish official newsreel, 1943-1970. Public Understanding of Science. 2005; 14: 393-408.

63. Lieberman, Sima. Growth and Crisis in the Spanish Economy: 1940-93. London: Routledge; 1995, p. 1-2; Newton, Michael T.; Donaghy, Meter J. Institutions of modern Spain. A political and economy guide. Cambridge: Cambridge University Press; 1997, p. 171. 
to the ferocious political repression of social groups like the miners, who were strongly committed to Republican values.

\section{The Silicosis Scheme in early Francoist Spain (1941-1946)}

Despite the desire to promote an image of rupture with the past and the abandoning of the ILO by Spain in 1939, the first decisions on silicosis by the new Labour Ministry were in fact characterised by a degree of continuity with the Republican approach. Those included intensifying medical supervision and health care facilities in the lead-mining industry, declaring compulsory the reporting of silicosis in all risk industries, and implementing compensation for sufferers. To some extent, this approach was built on cooperation between the Labour Ministry and the State Office of Public Health. The latter was under the Labour and Health Ministry during the Republican period but was incorporated into the Interior Ministry in the Franco regime.

In July 1940, the State Office of Public Health reorganised the FFAS, widening its competences to all occupational injuries caused by or prevalent in lead mining and metallurgy industries, namely silicosis, lead poisoning and ancylostomiasis ${ }^{64}$. The Foundation, renamed as Foundation for the Health Defence of Lead Industries and placed under the control of the Interior Ministry, was committed to carrying out periodical medical examinations and classifying workers for health care and preventive purposes. The Foundation remained responsible for the Silicosis clinic (reopened in late 1940) and Regional Ancylostomiasis Laboratory set up in 1927 under the hookworm campaign, both in Linares. In 1941, some 1,000 miners, all of the pit-workers employed in Linares lead mines and a figure equivalent to all workers attended during the Republican period, underwent medical and radiological examination. Further health surveys were carried out in Linares and in the Centenillo mines in 1942 and $1943{ }^{65}$.

The Foundation also extended its healthcare facilities. In March 1941, the Foundation applied for funding to the Work Accidents Compensation Board. The proposal included the extension of healthcare provision and the 
introduction of sickness benefits for silicotic workers ${ }^{66}$. However, funds were denied because the Labour Ministry was interested in leading any compensation initiative. In 1942, the Interior Ministry provided funds to enlarge the Silicosis clinic ${ }^{67}$.

Franco himself visited Linares in May 1943 and «spontaneously» suggested the construction of a hospital for miners as the culmination of the Foundation's work. The National Anti-Tuberculosis Foundation approved and funded the construction of a centre with 200 beds for silicosis and tuberculosis sufferers ${ }^{68}$. Consequently, the Foundation for the Health Defence of Lead Industries became incorporated in 1944 into the National Anti-Tuberculosis Foundation as its Silicosis and Pneumoconiosis Service ${ }^{69}$. The hospital building suffered several delays and was not completed until the late $1950 \mathrm{~s}^{70}$.

In March 1941, the Ministry of Labour issued regulations for the prevention and compensation of silicosis ${ }^{71}$. Inspired by the Labour Charter but acknowledging the contribution of the Republican Law of Occupational Diseases, the regulations covered all risk industries, including metal and coal mining, refractory industries, glass works, quarries, stone-works, tunnel construction and metallurgical works. Rather vague preventive regulations were contemplated to reduce dust emission although a provision was made for local ventilation machinery and masks. The regulations introduced the medical monitoring of exposed workers through annual medical and radiological examinations and the screening of newcomers to the industry. Those suspected or diagnosed as silicotics at an early stage could be remove from exposed jobs and relocated in dust-free workplaces. Finally, silicosis sufferers were entitled to compensation.

With the arrival of the Falangist José A. Girón de Velasco (1911-1995) to the Labour Ministry in May 1941, the approach to the silicosis issue

66. Propuesta al Consejo en relación al acuerdo del Patronato de Defensa Sanitaria de las Industrias del Plomo. 13 March 1941. HANII, file 46, sub file 1, document 14.

67. HACL, file 2053/024.

68. HACL, files 0543/07, 1922/061.

69. Hernández Pacheco, Diego. Servicio de Silicosis y Neumoconiosis en general. In: Benítez Franco, B. Información sobre la Lucha Antituberculosa en España y Memoria correspondiente al año 1944 presentada por el Secretario General del Patronato Nacional Antituberculoso. Madrid, Patronato Nacional Antituberculoso; 1945, p. 111-113.

70. HACL, file 1927/054. Córdoba de los Ríos, José. Sanatorios. Linares. Revista mensual ilustrada. 1952; 1 (7): 7.

71. BOE. 18 March 1941: 1873-1875. 
radically changed, making the former regulations redundant. In September 1941, a compulsory insurance scheme for silicosis was established. The regulations for the scheme were approved in November 1942 and it officially started in January $1943^{72}$. In 1946, there were some regulatory modifications and in 1947 the scheme was included in the «Occupational Diseases Insurance» ${ }^{73}$.

The core of the scheme was the system for compensating workers who were so badly affected by silicosis that they could not longer work or, if they died, for compensating their dependants. Silicotics who were retired and the families of those who had died when this legislation came into force were also eligible for compensation by retroactive application of the scheme. Benefits ranged from $37 \%$ to $50 \%$ of nominal salaries, which were increased in 1946 to $55 \%$ and $75 \%$, respectively. At any rate, these theoretically high benefits were engulfed by inflation and the scarcity of basic goods ${ }^{74}$.

As in former regulations, the scheme introduced initial and periodic medical examinations, relocating workers diagnosed with first-degree silicosis to dust-free workplaces. Finally, the scheme included loose preventive recommendations without the implementation of statutory regulations.

The scheme was managed by the Labour Ministry and was entirely funded by employers through a levy on the industry. In 1944, the direct administration of the Scheme was entrusted to an Administrative Council, with representation of employers and workers from the vertical trade unions. The Council was responsible for granting compensation to applicants, for establishing the levy for each industrial group depending on the level of risk, and for deciding which industrial sectors should be included in the scheme. To this end, all cases of silicosis in any industry had to be reported to the Council ${ }^{75}$.

In contrast to the wide cover of previous regulations, the Silicosis Scheme had a very narrow scope. In 1941, only lead and gold mining and the refractory industry were covered by the insurance. Eventually, in January 1944, the scheme was widened to include coal mining ${ }^{76}$. Extension of the

\footnotetext{
72. BOE. 7 January 1942: 112-114; BOE. 20 November 1942: 9404-9407.

73. BOE. 9 April 1946: 2650-2656; BOE. 21 January 1947: 486-490.

74. García Piñeiro, n. 3, p. 38-40.

75. BOE. 10 January 1945: 346-347.

76. Coal mining was included in the scheme after the WACB carried out a large-scale health survey of Asturian coal miners. The report, never published, painted a gloomy picture with a high rate of silicosis incidence, poor working conditions and a lack of preventive measures. BOE. 2
} 
scheme was mainly prevented by the economic burden implied, especially if the so-called «revolutionary» principle of retroactive compensation had to be applied. This was the case of iron-mining in the Basque Country. In 1943, the Government had announced its imminent inclusion into the scheme but this was prevented by employers' resistance ${ }^{77}$.

The attitude of employers towards their inclusion in the compulsory scheme ranged from open rejection to full acceptance. The latter was the case of gold mining. In 1940, the Rodalquilar mines were confiscated under the autarchic legislation, and in 1943 mining was started by ADARO, a subsidiary of the state-owned National Industrial Company. Surprisingly, given the small workforce and short period in operation, 157 former miners applied for and were granted retroactive silicosis compensation ${ }^{78}$. Propaganda played an essential role in presenting silicosis as a legacy from the former operators to be contrasted unfavourably with the paternal and rapid generosity of the New State in providing compensation and solving the problem.

The case of refractory industries was quite different. Widely distributed throughout the country in small family companies, employers practiced passive resistance to participation in the scheme, which paralleled the lack of governmental will to enforce the law. By December 1942, when the voluntary deadline to join the scheme came to an end, only 5 firms had registered, covering 317 workers. Registrations increased during the 1940 s, so that 1,507 firms were included in the scheme by 1949 , covering some 30,900 workers. The great variety of productive processes involved, the diverse nature of materials employed and the wide range of levels of exposure led to companies being considered in four categories: china and feldspar industry, refractory and abrasive industries, glazed pottery, and ordinary pottery. The last two categories, considered to carry the lowest level of risk, included more than $50 \%$ of the workforce. The number of workers granted compensation was very low. In the five-year period from 1946 to

February 1944: 938-940. HANII, file 46, sub file 5, document 9. For an overview on large-scale studies conducted into coal dust disease in the interwar period, see Mclvor; Johnston, n. 2, p. 74-77.

77. Izquierdo Laguna; García Sainz, n. 20, p. 232. Metal mining and quarries - other activities with a well-known risk - employed more than thirty thousand men in 1950.

78. Informe a la Junta Administrativa del Seguro de Silicosis. 24 April 1945. HANII, file 46, sub file 3 , document 7 bis. 
1950 , only 159 workers were compensated, with $70 \%$ of them belonging to the first two categories ${ }^{79}$.

Strong resistance was also shown by companies in lead mining. In a propagandistic campaign, the Minister of Labour visited the mining district of Jaén in June 1942 and speeded up compensation to retired silicotics and the families of sufferers who had died, granting a credit to allow payments to be made. 446 applications were registered and 329 (74\%) were eventually granted. One out of three of these payments was funded by the WACB as an example of collaboration with the industry and social commitment. Neither this contribution nor the active engagement and influence of the National Lead Producers Association in the drafting of the scheme prevented growing conflict with the WACB. In April 1945, the Director of the Board described the cooperation of firms with the scheme as «heart-breaking». Employers traditionally complained about the economic burden that the scheme placed on an industry in crisis and about their difficulty in replacing specialised workers declared unfit to work after the compulsory medical examination. Pressure from the employers reaped rewards: lead miners were released from military service and the levy on the industry was reduced. Participation in the scheme grew: in 1943, it included 36 firms covering 4,806 miners and in 1951, 92 firms covering 9,079 miners, practically the whole sector. However, the opposition of employers persisted. Compulsory medical examinations were carried out at a slow pace. By 1945 , only $68 \%$ of affiliated men had been examined. In 1943, managers even refused to suspend from work employees who had been declared unfit by the examination, and many men diagnosed with first-degree silicosis continued to be employed in work that involved exposure. Finally, companies regularly refused to pay insurance premiums ${ }^{80}$.

Coal mining employers showed little reluctance and preferred to meet formal governmental demands, becoming engaged in the scheme without delay. The number of workers covered ranged from 72,400 miners in 1944 to more than 88,700 in 1951 , matching the increase in the workforce ${ }^{81}$. Nevertheless, compulsory medical examinations progressed very slowly. Officially, this was because of the large size of this group and the shortage

79. Informe de la Dirección Técnica del INP. 4 September 1951. HANII, file 46/1, sub file 8, document 7.

80. Informe a la Junta Administrativa..., n. 78.

81. Informe de la Dirección Técnica del INP, n. 79. 
of X-ray plates and other supplies. In fact, employers hampered examinations, which could withdraw from the labour market skilled workers in great demand, posing a threat to production ${ }^{82}$.

Vertical unions kept a very low profile in this early stage, paralleling the attitude of passive rejection adopted by Spanish workers in the postwar years. A more active role was played in the late 1940s and early 1950s, when workers started to use the Francoist labour institutions to defend their interests, particularly the Provincial Labour Tribunals, created in 1938 under the Labour Charter ${ }^{83}$. Thus, the unions began to issue some declarations against abuses, especially the failure to remove first-degree silicotics from face-work and their loss of purchasing power when transferred to surface work ${ }^{84}$.

The application of strict criteria during the 1940s minimized the number of silicotics approved for compensation under the Silicosis Scheme ${ }^{85}$. From 1941 to 1950, only 6,027 workers were granted compensation, mostly coal miners (79\%). Figure 2 shows the total number and percentage of workers awarded compensation in these three main industries during the fiveyear period from 1946 to 1950 (total number: 4615). Gold mining has not been included as only eight workers were granted compensation in that period. As can be seen in Figure 3, lead mining remained the highest-risk occupation in terms of silicosis compensation. In the five-year period from 1946 to 1950, 706 workers were granted compensation. This represents a compensation rate of $10.3 \%$ of the workforce during the five-year period, ten times the rate in the refractory industry and almost double the rate in coal mining.

\section{Conclusions}

The existence of a significant gap between declared social policies and their implementation at the workplace is not the sole prerogative of a dictator-

\footnotetext{
82. García Piñeiro, n. 3, p. 94.

83. Molinero; Ysàs, n. 58, p. 189. The most frequent disputes in silicosis compensation lawsuits that came before these tribunals were over the degree of disability and corresponding benefits. Benito del Pozo, n. 3, p. 353-356.

84. Díaz Martínez; García Fernández, n. 3, p. 120-121.

85. García Piñeiro, n. 3, p. 94.
} 


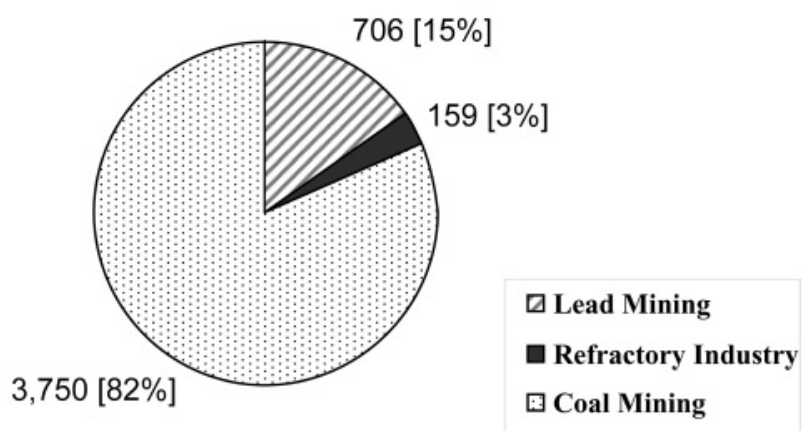

Figure 2. Workers awarded compensation under the Silicosis Scheme by industrial sector, 19461950. Source: Informe de la Dirección Técnica del INP. 4 September 1951. HANII, file 46/1, sub file 8 , document 7.

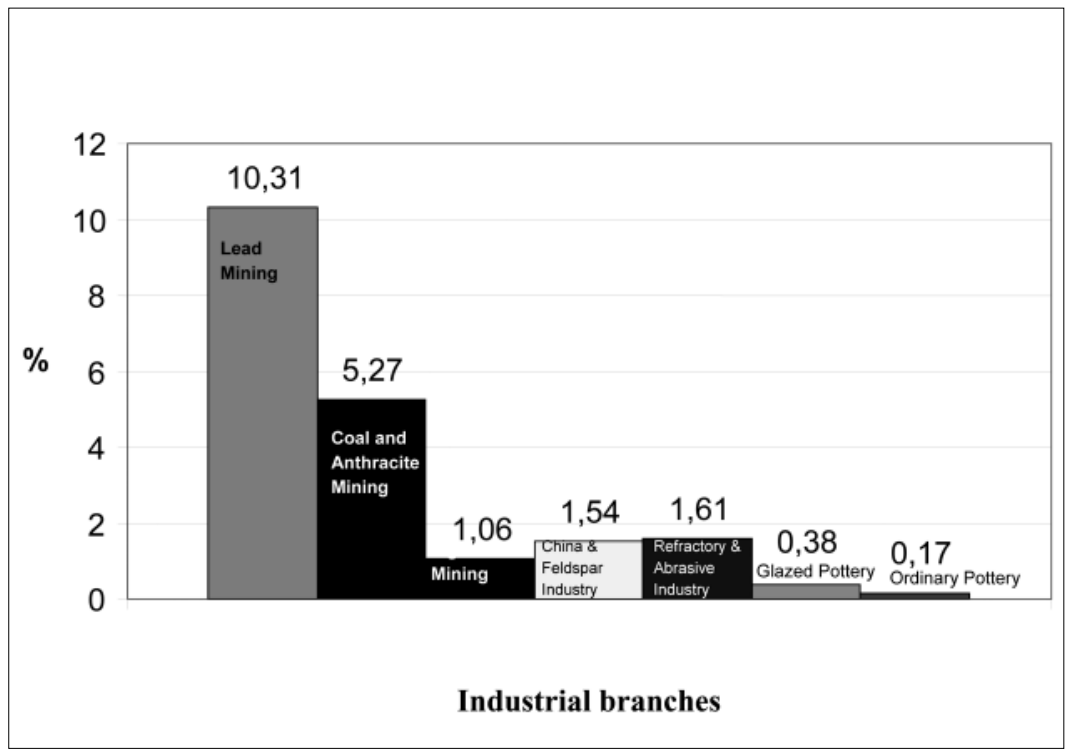

Figure 3. Percentage of workers awarded compensation by industrial sector, 1946-1950. Source: Informe de la Dirección Técnica del INP. 4 September 1951. HANII, file 46/1, sub file 8, document 7. 
ship. In the case of the campaign against silicosis in early Francoist Spain, the propagandistic nature of the regime's social policy, the harsh restriction of workers' freedoms and the lack of governmental will to enforce the law all contributed to widening this gap.

While the initial decisions taken by the new State followed the Republican approach to silicosis, a radical change was imposed in May 1941 by the arrival of members of the fascist party to head the Labour Ministry. Social insurance and compensation were prioritised, to the detriment of medical supervision and technical prevention. Employers' reluctance to become involved in the insurance scheme, its narrow coverage, the application of strict criteria for compensation entitlement and the low payments all contributed to minimise the benefits of social insurance despite its propagandistic use.

Republican labour and health administrators, following ILO guidelines, soon recognised the significance of silicosis. This period also saw the development of a more comprehensive approach to occupational health. It was embodied in several organisational changes designed to strengthen the links between the preventive dimension and social insurance policies, changes that were poorly implemented due to political crisis and the outbreak of the Civil War.

\section{Acknowledgments}

I gratefully acknowledge the kind assistance received from Anselmo Barreales at the Historical Archive of the National Insurance Institute (Madrid) and Luis Rabaneda at the Historical Archive of the City of Linares (Jaén). Earlier versions of this article were presented at the International conference «Working with Dust: Health, Dust \& Diseases in the History of Occupational Health» (University of Exeter, April 2006) and the Workshop of the Interwar Health Network «Crisis as opportunities in interwar health?» (Granada, April 2007). I am grateful to participants for their valuable comments. I also thank Manuel Baselga, Paul Blanc, Javier Silvestre, and the anonymous referees and editors of this dossier for their helpful suggestions. 